\title{
超大型三軸圧縮試験による実物補強材で補強した砂の強度特性 STRENGTH CHARACTERISTICS OF SAND REINFORCED WITH FULL SCALE REINFORCING MATERIALS IN LARGE SCALE TRIAXIAL COMPRESSION TEST
}

\author{
福 島 伸二*・望月美登志**・香川和夫*** \\ By Shin̈̈ FUKUSHIMA, Yoshitoshi MOCHIZUKI and Kazuo KAGAWA
}

\begin{abstract}
A reinforcing mechanism, and strength and deformation characteristics of the reinforced soil have been investigated by a laboratory element test using a small size specimen. However, the properties of soil that reinforced with a full scale reinforcing material can not be studied by the laboratory test as the size of specimen is very small.

In this paper, a series of large scale triaxial compression tests were performed in order to investigate the strength and deformation characteristics of sand that reinforced with full scale reinforcing materials (geo-grid, non-woven and metal strip for Terre armee). The tests were carried out on a dry sand sample, the results were represented by comparing the stress-strain relation of reinforced sand with that of unreinforced sand.
\end{abstract}

Keywords : reinforcement, triaxial compression test, sand, reinforced earth

\section{1. まえがき}

補強土工法は，土以外の合成織維材料や金属製の帯材 などの引張に強い材料（補強材）を土が伸びる方向に配 置し，土と補強材との間に発生する摩擦により土の伸び 変形を拘束して地盤を補強するものである. 最近，この 補強土工法を適用した盛土や切取斜面が数多く建設され るようになってきた．今後はさらに適用分野が広がり， 高盛土や長大切取斜面のような大規模な土構造物へも補 強土工法が適用されてゆくものと考えられる.

これまで補強材を地盤中に配置したときの補強メカ二 ズムや補強効果は, 供試体寸法の小さい小型室内要素試 験（三軸圧縮・平面ひずみ圧縮試験など）を用いた，主 にモデル補強材で補強した土のせん断試験により調べら れてきだ1).2). しかし，これらの試験では供試体寸法が 小さいため実物の補強材の効果を調べることは不可能で ある. 特に, 補強土工法を大規模な土構造物の建設に適 用してゆくためには実際の補強材が地盤中に配置された ときの効果を把握しておく必要がある.そこで本報告は

* 正会員 工博 フジタ工業(株)技術研究所トンネル研究 室 ( ₹223 横浜市港北区大楖町 74)

** 正会員 工修 フジタ工業(株)技術研究所トンネル研究 室 (同上)

*** 正会員 工修 フジタ工業(株)技術研究所トンネル研究 室長 (同上)
供試体寸法が大きい超大型三軸圧縮試験機を用いて，実 際の補強材が現実にあり得る間隔で砂地盤中に配置され たときの効果について実験的に調べた結果についてまと めたものである.

今回実施した超大型三軸圧縮試験は要素試験涪1)であ るが供試体が大きいので，図一1に示すように補強材を 配置した供試体は部分的に実際の補強地盤と考えること もできる.したがってこの試験により実際の補強材の効 果をかなり正確に調べることができるものと考えられ る.

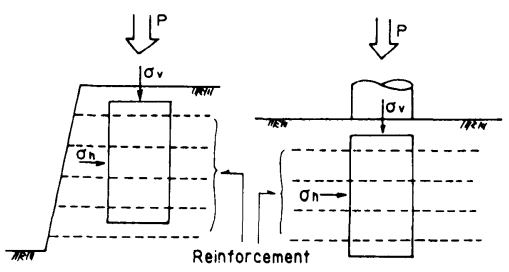

図一1超大型三㣙供試体と補強地盤との対心

注 1）供試体内に補強材が配置されると供試体内の応力状態 は一様ではなく非常に複雑なものになり要素試験と考え にくいが、ここでは供試体の境界条件が明確でかつ拘束 圧も制御できるという意味で要素試験として扱うことに する. 


\section{2. 試験方法}

\section{（1）超大型三軸圧縮試験機}

本報告で使用した超大型三軸圧縮試験機は粗粒材の力 学的特性を調べる目的で開発されたもので, 供試体の寸 法は直径 $d_{s}=120 \mathrm{~cm}$, 高さ $h_{s}=240 \mathrm{~cm}$ である ${ }^{3)}$. 図一 2 にこの試験システムの全体図を示してある．側圧 $\sigma_{c}$ はコンプレッサーからの高圧縮空気圧をレギュレータに より所定の圧力に制御して, 供試体体積変化測定用夕ン ク（TA）内で水王に変換して加える. また軸荷重の載 荷は，油圧ユニットからの油圧油を載荷シリンダー内に 一定量ずつ流し込み，載荷プランジャーにより供試体を 圧縮して行う. 軸変位速度は油圧ユニットからの油量を 流量調節弁で調節するが, 今回の軸変位速度は $\varepsilon_{a}=0.3$ \%/min とした．試験はすべて排気条件で実施したが， このときの供試体の体積変化量は, 供試体の体積変化分 だけの水が三軸セル内から夕ンク TAに流出入するよ うにしておき，このタンク内の水位を差圧計により測定 して求める．載荷プランジャーが三軸セル内に貫入する と, その貫入した容積分の水はそれぞれ載荷プラン ジャ一の半分の断面積をもつ補正シリンダー (CA, CB) に流入する．こうすることにより載荷プランジャ一貫入 による三軸セルからのタンク TA への水の流出をなく し, タンク $\mathrm{TA}$ へは供試体の体積変化分だけの水が流 出入することになる.

供試体の上下端面は,この面が主応力面となるように， 図一3に示すように厚さ $0.5 \mathrm{~mm}$ のゴムシートをキャッ プあるいはペデスタルにシリコンシーラント（タイルメ ント社 H-型) で接着し，さらにシリコングリース（信 越化学 $\mathrm{KS} 63 \mathrm{G}$ ）をはさんでゴムシートを置いて摩擦を 除去した。

(軸応力・側方応力の計算)

本試験は寸法の大きい供試体を用いているので, 供試

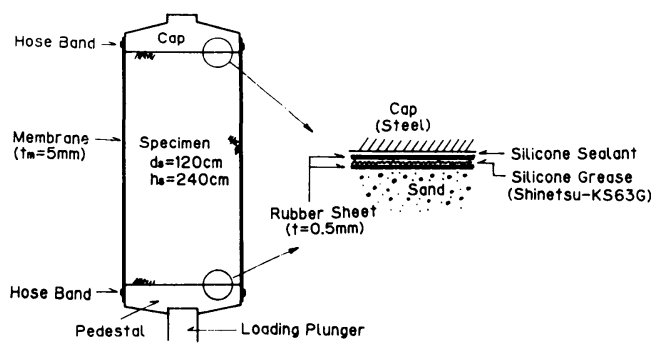

図一3 供試体の端面条件

体に作用している応力を求めるには供試体の自重, セル 水位（供試体の高さ方向にセル水圧が異なる），ゴムス リーブによる供試体の変形の拘束などの影響を考慮する 必要がある. 軸応力 $\sigma_{a}$ は供試体の自重の影響を考慮し て，図一4に示すように供試体中央部（高さ $h_{s}$ の $1 / 2$ の位置) で計算している.キャップ上部の水の重量は供 試体下面から夕ンク TA 内の水面までの高さを $h_{B}$ $\left(=h_{B O}+\Delta h_{B}\right)$ とすると

$$
W_{w}=\left(A_{s}-a\right)\left(\Delta+h_{B}-h_{T P}\right) \gamma_{w}
$$

となるここで $\Delta$ は三軸セル上面からキャップ上面ま での平均高さである，そして $P_{a}$ をロードセルによる軸 荷重の測定値， $W_{c}$ をキャップ重量， $\gamma_{d}$ を供試体の乾燥 密度として, 鉛直方向の力のつり合いから，供試体中央 部の軸応力は

$$
\sigma_{a}=\left(P_{a}+W_{c}+W_{w}\right) / A_{s}+\sigma_{c}\left(1-a / A_{s}\right)+\gamma_{d} h_{s} / 2
$$

となる．またゴムスリーブの外側から作用する側方応力 $\sigma_{r}$ は供試体中央部で水平方向の力のつり合いから次式 のようになる.

$$
\sigma_{r}^{*}=\sigma_{c}+\left(h_{B}-h_{s} / 2\right) \gamma_{w}
$$

そして求めるべき供試体に作用する側方応力は以下に示 すゴムスリーブの拘束力の補正（式（ 3 ））をした

$$
\sigma_{r}=\sigma_{r}^{*}-\Delta \sigma_{r m}
$$

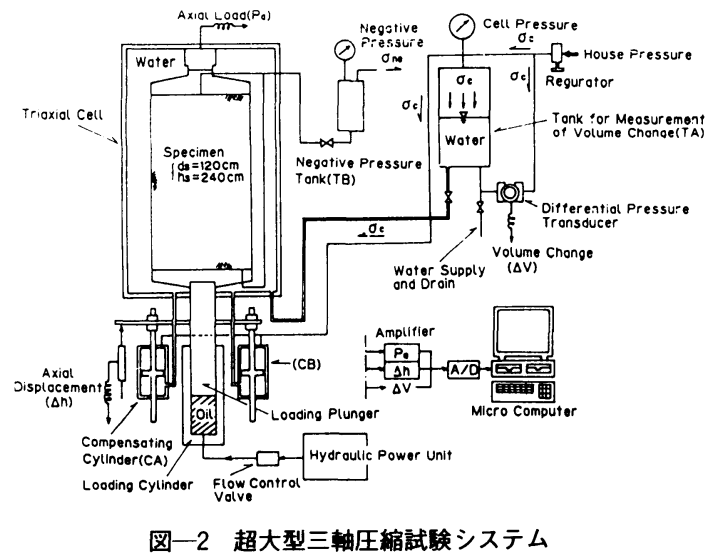

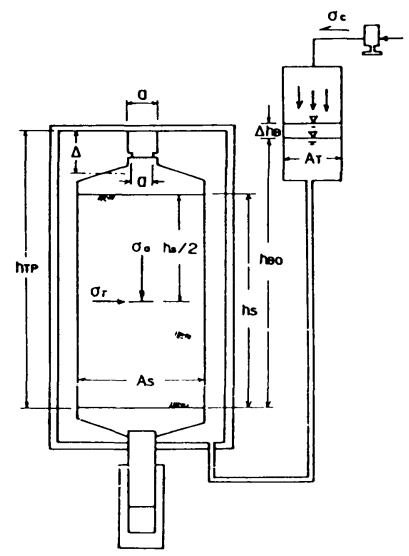

図一4 供試体の応力の計算 
である.

(ゴムスリーブ拘束力の補正)

ゴムスリーブによる供試体の変形の拘束による影響は 以下に示す考え方により補正した．試験後の供試体の観 察によると，ゴムスリーブは供試体を軸方向に圧縮する と軸方向に座屈している．したがって，ゴムスリーブは この方向に供試体を拘束しないが, 横方向への供試体変 形を拘束するものと考えられる．このため側方応力のみ ゴムスリーブが理想的な弾性薄肉円筒として供試体とと もに変形するものとしてゴムスリーブの拘束力を求めて 補正する. つまり供試体の側方ひずみを $\varepsilon_{r}$ として水平 方向の力のつり合いから補正値は,

$$
\Delta \sigma_{r m}=2 t_{m}\left(\sigma_{r}^{*}-E_{m} \varepsilon_{r}\right) / d_{s}
$$

となる.ここで， $t_{m}, E_{m}$ はゴムスリーブの肉厚とヤン グ率で, 今回使用したゴムスリーブはそれぞれ $t_{m}=0.7$ $\mathrm{cm}, E_{m}=45 \mathrm{kgf} / \mathrm{cm}^{2}$ である.

\section{（2）供試体の作製方法}

試験に使用した試料は豊浦砂 $\left(G_{s}=2.64, e_{\max }=\right.$ $\left.0.977, e_{\min }=0.605\right)$ である. 供試体は以下に示すよう に作製した．まずゆる詰状態の供試体は空気乾燥状態に ある砂を多重ふるい（4 層でふるい目の組合せは上から $9.54,4.76,4.76,4.76 \mathrm{~mm})$ により約 $80 \mathrm{~cm}$ の高さか ら自由落下させて作製した (空中落下法).このときの 供試体の間隙比は約 $e=0.84 \sim 0.88\left(D_{r}=34 \%\right)$ である. また密詰め状態の供試体は，ゆる詰の供試体と同じよう

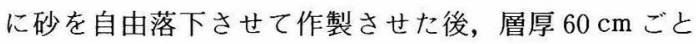
にバイブレーターにより加振して作製した．このときの 供試体の間隙比は約 $e=0.68 \sim 0.70\left(D_{r}=70 \%\right)$ である.

試験に使用した補強材は実際に現場で使用されること のある次の 3 種類で，これを図一5(a)，写真一1に示す ような形状にして供試体内に配置した.

(1) ジオグリッド：ポリプロピレンを原材料とする格 子状の材料で, これを直径 $110 \mathrm{~cm}$ の円板に切断し たもの（テンサーSS-2, 格子の目合寸法は $28 \times 40$ $\mathrm{mm})$

(2) 不織布：ポリプロピレン $100 \%$ の連続長繊維よ りなる布状の材料で，これを直径 $110 \mathrm{~cm}$ の円板に 切断したもの

(3) ストリップ材：テールアルメ工法で使用されてい る金属製の帯状材料（リブなし（幅 $10 \mathrm{~cm} ）$ とリブ 付き (幅 $6 \mathrm{~cm}))$ を長さ $110 \mathrm{~cm}$ に切断し，その中 央部で 3 枚交差させたものを 1 層とする

補強した供試体は以下のように作製した。砂の部分は 上述した方法で作製するが，補強材は図一5(b) に示す

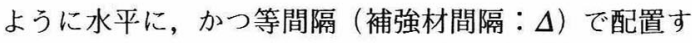
る.ここで補強材層数 $(n)$ と補強材間隔の関係は $h_{s}=$ $n \cdot \Delta$ である.

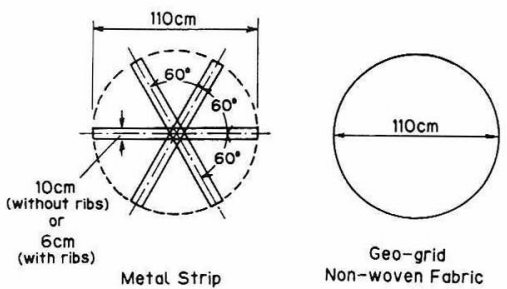

図一5(a) 補強材の形状と寸法

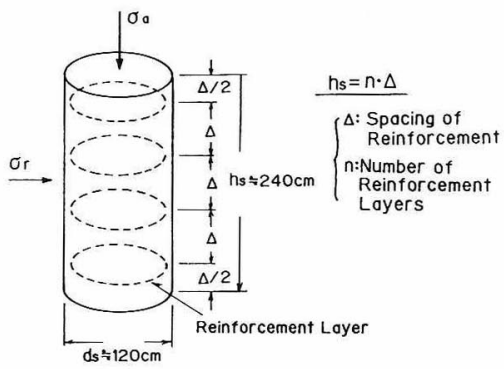

図一5(b) 供試体中への補強材の配置

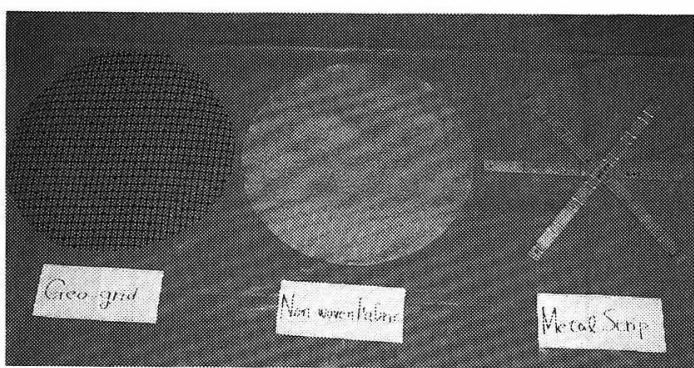

写真一1 補強材

なお, 供試体の密度は圧密圧 $\sigma_{r c}=0.5 \mathrm{kgf} / \mathrm{cm}^{2}$ にお ける間隙比 $e_{0.5}$ で示してある.

\section{3. 試験 結 果}

図一6に各種補強材をそれぞれ供試体中に 4 層配置し て補強した砂の応力比一軸ひすみ関係を比較してある. この図からストリップ材で補強した砂は他の材料に比較 して供試体の変形が小さいうちから効果が現われてい る. しかし $\Delta=60 \mathrm{~cm}$ 程度の間隔で補強材を配置して補 強した砂の応力比一ひずみ関係は, 材料により多少の差 があるものの, 最大応力比 $\left(\left(\sigma_{1} / \sigma_{3}\right)_{\max }\right)$ の增加量は材 料によらずほぼ同量であることがわかる.

図一7にはリブなしとリブ付きのストリップ材で補強 した砂の応力比ーひずみ関係を比較してあるが，リブな しストリップの方がやや補強効果が大きいことがわか る. ストリップ材の引抜試験結果によればリブ付きスト リップの方がリブなしに比べて摩擦係数が大きくなって おり ${ }^{4)}$ ここで得られた結果と逆の傾向になっている. 


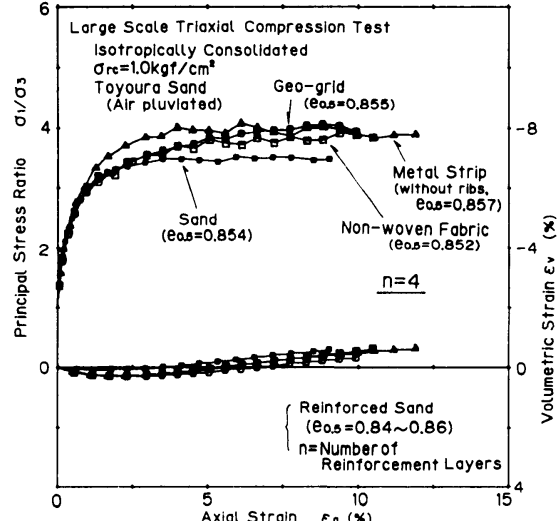

図一6 各種補強材により補強した砂の心力比-ひずみ関係

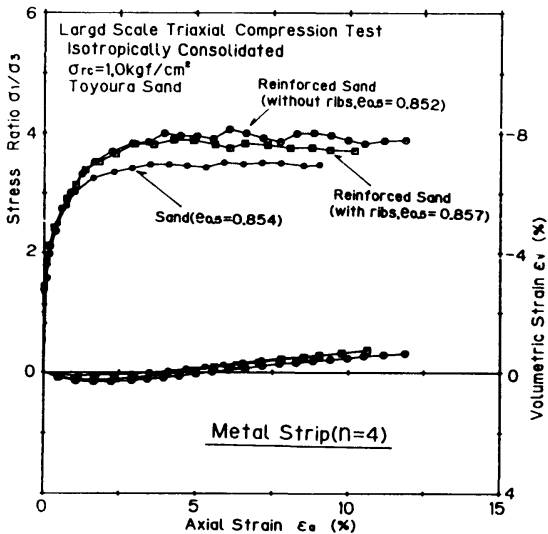

図一7 ストリップで捕強した砂の応力比-ひずみ関係

次に図一8(a), (b) に層数を $n=2,4,8$ と変えてジ オグリッドで補強した砂の応力比-ひずみ関係を示して ある.また図一 9,10 にはそれぞれ不織布，ストリップ 材（リブ付き）で補強した砂の応力比ひずみ関係を示 してある.これらの図から，補強材層数が多くなるほど， つまり補強材間隔が小さくなるほど補強効果が大きくな ることがわかる. また 3 種の材料のうちで特徴的なのが ジオグリッドで補強した砂で，他の材料に比べて補強効 果が最も大きいが，せん断変形がある程度生じると応力 比は急に低下する．この傾向は補強材層数が多いほど影 著である.この応力比が急に低下するのはジオグリッド が破断した結果と考えられる。たとえば図一11には $n$ =4 層のジオグリッドで補強した密詰め砂の軸荷重-軸 変位関係 $(X-Y$ レコーダの記録) を示してあるが，こ の図で軸荷重が急に低下したときに三軸セル内からバキ バキというような音が聞こえてきた。この音がジオグ リッドが破断するときのものと思われる。図一8(a) と (b) からこの応力比-ひずみ曲線が急に低下するとき

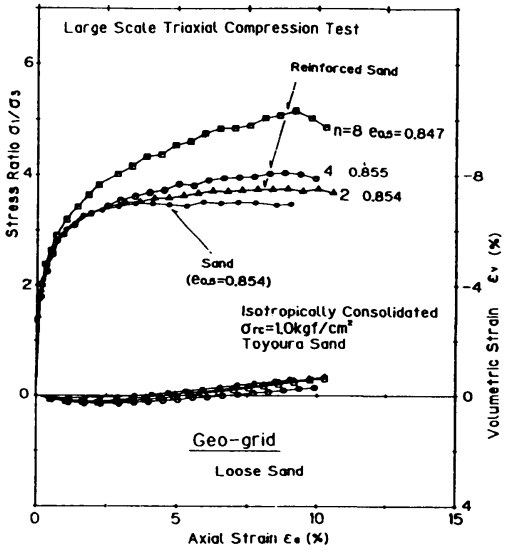

(a) ゆるい砂

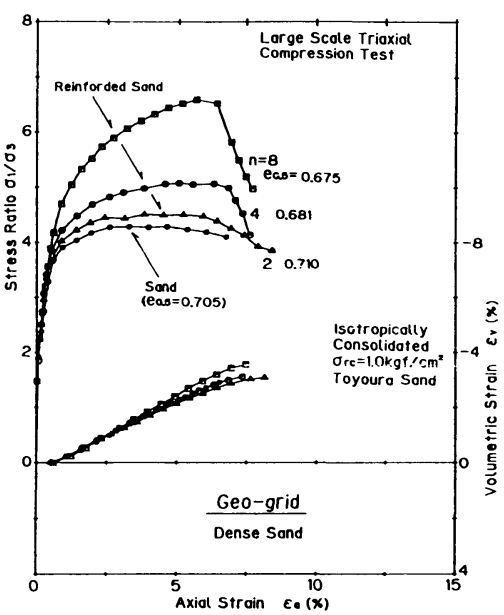

(b) 密な砂

図一8ジオグリッドで捕強した矷の応力比-ひずみ関係

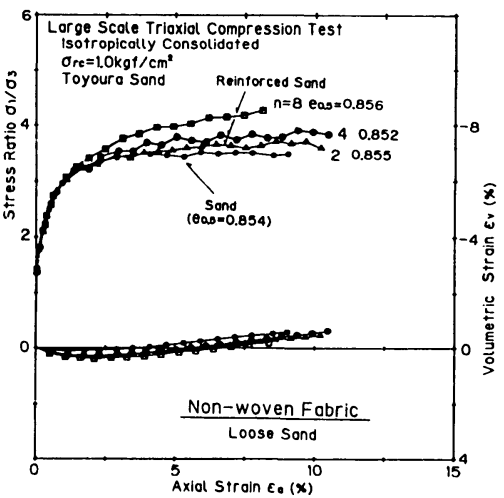

図一9 不識布で補強した础の応力比ーひずみ関係 


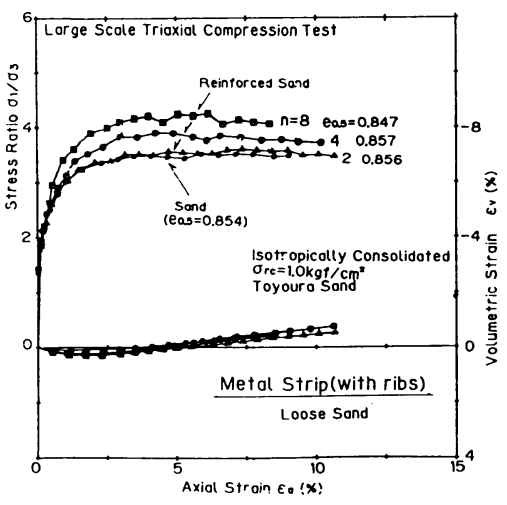

図一10 ストリップで補強した砂の応力比ーひずみ関係

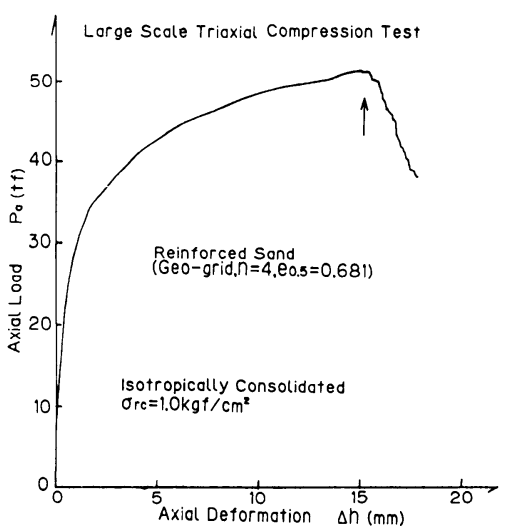

図一11軸荷重-軸変位関係 $(X-Y$ $Y$ コーダの記録 $)$

の軸ひずみ量は砂の密度により異なり，密な砂の方が小 さいことがわかる，以上のことから，ジオグリッドを用 いて地盤を補強するときは材料自体が破断するときの変 形量を考慮する必要があろう.

次に補強材層数の影響をみるために，図一8，9，10 か ら最大応力比を読み取り, 補強材層数に対してプロット したのが図一12(a)，(b) である．またこの図の縦軸に は補強材による最大応力比の増加率と内部摩擦角 (粘着 力成分 $C=0$ としている)

$$
\phi=\sin ^{-1}\left[\left\{\left(\sigma_{1} / \sigma_{3}\right)-1\right\} /\left\{\left(\sigma_{1} / \sigma_{3}\right)+1\right\}\right]
$$

のスケールもそれぞれ示してある.これらの図から補強 材層数が増加すると補強効果が急に増加すること，また 材料の種類による効果の差も大きくなることがわかる.

しかし実際の補強地盤における補強材間隔が一般に 70 〜100 cm であることを考えると, 図一12(a) からこの 間隔における補強効果は材料によりほとんど差がない か, あってもその差は小さいことがわかる.そしてこの $70 \sim 100 \mathrm{~cm}$ 間隔で補強材を実際の地盤に配置したとき の効果は, 最大応力比の增加分で 1 2 割程度で, この

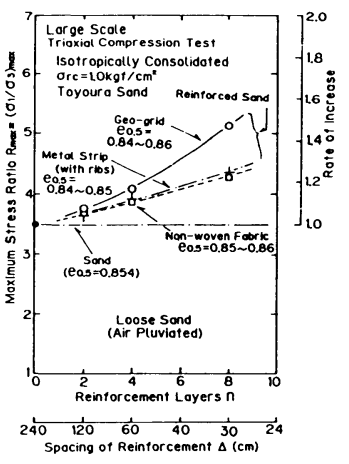

(a) ゆるい砂

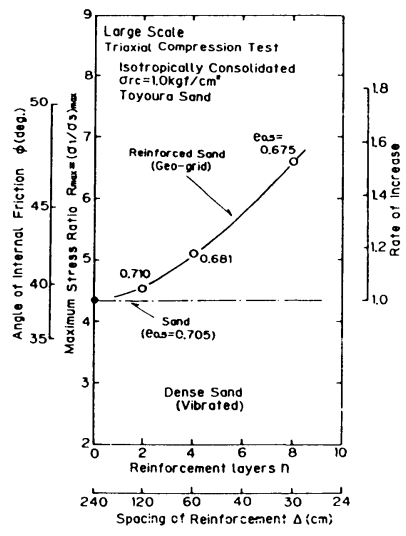

(b) 密な砂
図一12 補強材首数と博強効果の関係

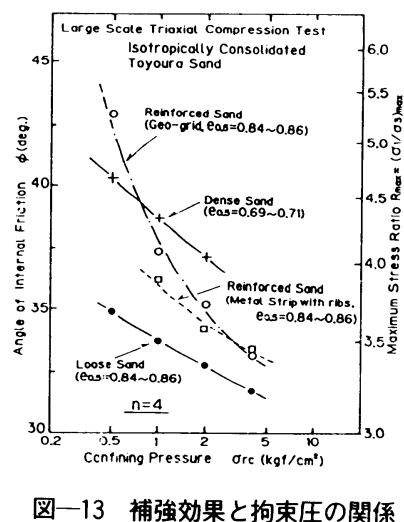

値は内部摩擦角で表わすと $3 \sim 4$ 度に相当している.

図一13には $n=4$ 層のジオグリッドとストリップ (リ ブ付き) で補強した供試体について拘束圧 $\left(\sigma_{r c}\right)$ を変え た試験をしたときの内部摩擦角（あるいは最大応力比） を拘束圧に対してプロットしてある．この図からジオグ リッドとストリップとで補強効果と拘束圧の関係に相違 があることがわかる.つまりストリップによる補強効果 $(\Delta \phi)$ は拘束圧によらずほぼ一定であるのに対して，ジ オグリッドで補強した砂では拘束圧が低くなるほど $\Delta \phi$ は大きくなっている．これは両者の補強メカニズムの相 違によるものと考えられる.つまり，ストリップは砂に 一定の摩擦角を付加するような効果をもっている．これ に対して，ジオグリッドは砂のダイレイタンシー傾向が より大きい低拘束圧領域においてより大きな効果を示し ているから,グリッドと砂とのかみ合わせ(インターロッ キング）の効果が重要な役割をしているものと考えられ る。またジオグリッドは拘束圧が低くなるほぼ効果が大 きくなるが，拘束圧が高くなると逆にストリップの効果 よりも小さくなる傾向がある．このことは，この材料が 
比較的低い盛土のような土構造物の建設に適しているこ とを示していよう.

以上のような補強メカニズムの相違は Mohr の応力円 から求められる破壊包絡線（強度パラメーター: $C, \phi$ ) に反映する. 図一14(a)，(b)にはそれぞれジオグリッド， ストリップで補強した砂の Mohr の応力円 $\left(\left(\sigma_{1} / \sigma_{3}\right)_{\max }\right.$ 時）から求めた破壊包絡線を示してある.これらのうち 図一14(a) は拘束圧 $\sigma_{r c}=0.5,1.0,2.0,4.0 \mathrm{kgf} / \mathrm{cm}^{2}$ に おける試験から，また図一14(b) は $\sigma_{r c}=1.0,2.0,4.0$ $\mathrm{kgf} / \mathrm{cm}^{2}$ における試験から求めた破壊包絡線である. 図 中にはこの破壊包絡線から求めた内部摩擦角 $(\phi)$ が示し てある。なお，図中の（a）之（b）における無補強砂 の破壊包絡線は供試体数の違いにより若干の差異を生じ ているが、これは同等とみなすべきものでありこの図か ら大略的に次のことがいえる.すなわちこれらの図から， ジオグリッドとストリップで補強した砂の破壊包絡線は 異なっており，ジオグリッドで補強した砂は無補強の砂 に比べて内部摩擦角はほとんど同じであるが粘着力成分 のみが増加している $(\Delta \phi=0, \Delta C>0)$.これに対して ストリップで補強した砂は無補強の砂に比べて内部摩擦 角のみが増加している $(\Delta \phi>0, \Delta C=0)$ ．このことは 補強した砂の強度パラメーターは補強材の効果として $C$ のみが増加するか， $\phi$ のが増加するか，あるいは

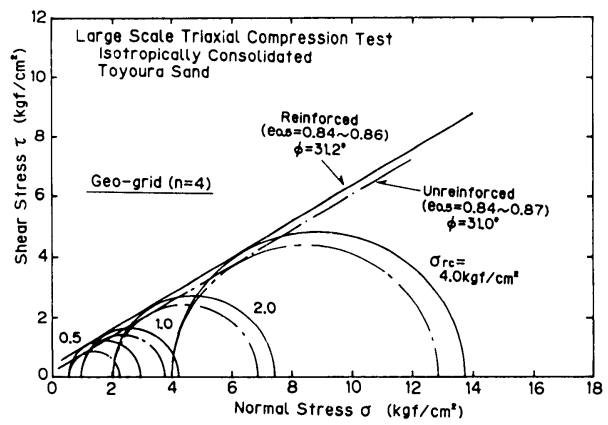

(a) ジオグリッド

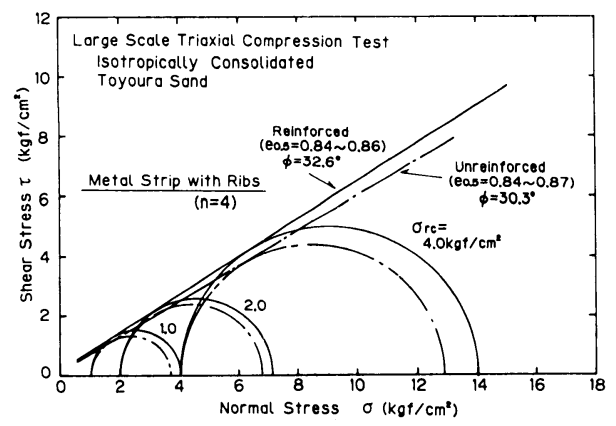

( b ) ストリップ

図一14 ジオグリッドで補強した砂の破壊包絡線
$C, \phi$ ともに増加するかは補強材料の種類（材料により 補強メカニズムは異なる）によることがわかる.

\section{4. 小型三軸圧縮試験結果との比較}

小型三軸圧縮試験により補強した砂のせん断特性を調 べるときは，供試体寸法が小さいので補強材は実物では なく，一般にモデル化したものが用いられる。ここでは モデル補強材で補強した砂の小型三軸圧縮試験結果 (S-TC) と実物補強材を用いた超大型三軸圧縮試験結 果 (L-TC) と比較することにする.

小型三軸圧縮試験の供試体寸法は直径 $d_{s}=10 \mathrm{~cm}$, 高 さ $h_{s}=20 \mathrm{~cm}$ で, 供試体はロートを用いた空中落下法 により作製した，供試体の端面条件は超大型三軸と同様 に厚さ $0.3 \mathrm{~mm}$ のメンブレンシートを 2 枚用いて摩擦を 除去した. 試験時の供試体は飽和状態で, 背圧 $\sigma_{B P}=$ $1.0 \mathrm{kgf} / \mathrm{cm}^{2}$ を加えている.

試験に用いたモデル補強材は超大型三軸で用いた材料 と補強メカニズムができる限り似たものとなるように選 んだ次の 3 種類である。

(1) ジオグリッド：高密度ポリエチレン製の網状ネッ 卜（網目 $2.0 \times 2.0 \mathrm{~mm} ）$ を直径 $90 \mathrm{~mm}$ の円板状に したもの

(2) 不織布：超大型三軸圧縮試験で使用したものを直 径 $90 \mathrm{~mm}$ の円板状にしたもの

(3) ストリップ材：幅 $5 \mathrm{~mm}$ ，厚さ $0.5 \mathrm{~mm}$ ，長さ 90 $\mathrm{mm}$ の銅板にアラルダイトで砂粒子を付着させたも のを(平均厚さ $1.6 \mathrm{~mm})$, その中央部で 3 枚交差 させたものを 1 層とする.

これらの補強材は超大型三軸と同様に図一 5 に示すよ うに供試体内に配置した。

図一15(a)，(b)，(c) にそれぞれジオグリッド，不織 布，ストリップにより補強した砂の小型三軸圧縮試験の 結果を示してある.これらのうちジオグリッド,ストリッ プで補強した砂の応力比一ひずみ関係は補強材による強 度増加量は必ずしも一致していないが超大型三軸で得ら れたものと似ている。これに対して不織布で補強した砂 の応力比-ひずみ関係は超大型三軸のものと全く異なり, せん断初期から無補強の砂よりも弱くなっており，かな りの変形が生じてから補強材の効果が現われている。こ れは不織布の厚さが無拘束状態で約 $4 \mathrm{~mm}$ もあり, かつ 厚さ方向に変化しやすいため, これを寸法の小さい供試 体内に配置すると補強材間隔の大きさに対して材料自体 の変形が大きくこのような応力比-ひずみ曲線になるも のと考えられる。

実際の補強地盤や超大型三軸の補強した供試体では補 強材間隔が大きいので, 材料自体の変形量が大きくとも このような問題は生じないだろう。したがって，小さい 


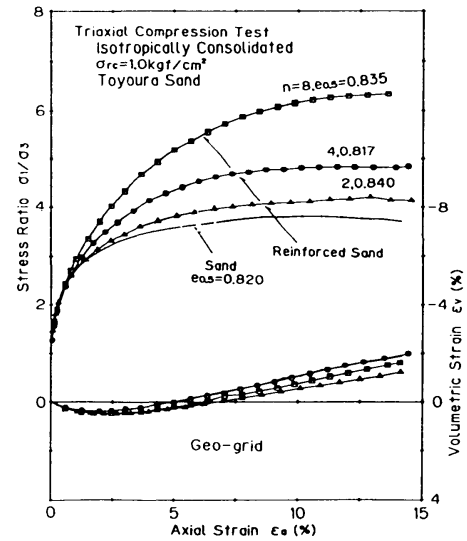

(a ) ジオグリッド

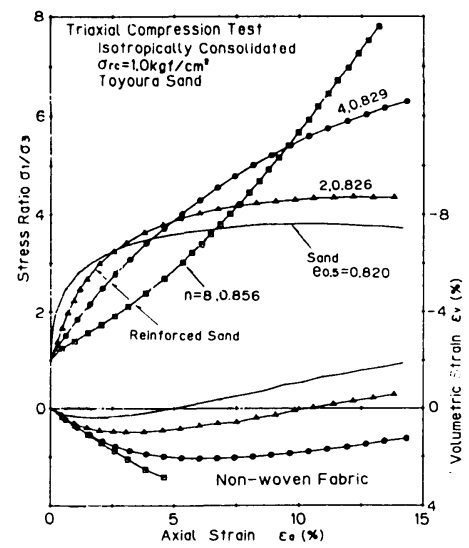

(b) 不織布

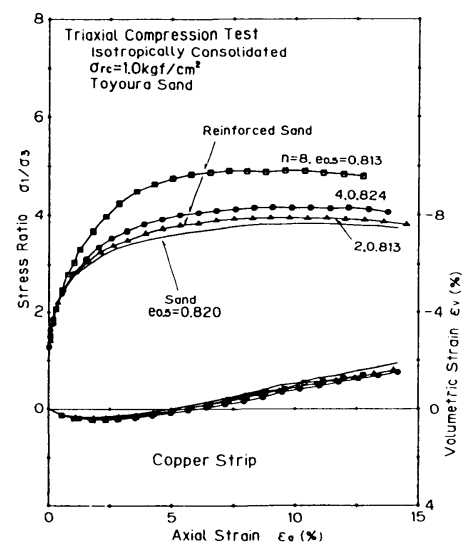

(c) ストリップ
供試体を用いて不織布のような材料で補強した砂の試験 をしても実際とは全く異なった挙動しか得られないこと になる。

図一16には小型と超大型三軸圧縮試験の供試体直径 $\left(d_{s}\right)$ と補強材間隔 $(\Delta)$ の比 $\left(d_{s} / \Delta\right)$ と補強効果の関係を 示してある (不織布は除く).この図からモデル化した 補強材であっても上述したような補強材自体の変形が及 ぼす影響がなければ，小さい寸法の供試体を用いた小型 三軸圧縮試験でも補強材間隔と供試体寸法の比で整理す れば超大型三軸圧縮試験による実物補強材の効果を定量 的には難しいが定性的には評価できることがわかる．特 にストリップで補強した砂の試験では供試体寸法に関係 なく両者はよく似た傾向を示している．以上のことは， 相似率の問題も無視できないが図一17に示すように幾 何学的に相似（たとえば $D / \Delta$ を一定とする）な模型補 強地盤 $\left(D_{m}, \Delta_{m}\right)$ の試験から実際の補強地盤 $\left(D_{\rho}, \Delta_{\rho}\right)$ の 挙動を推定することがある程度可能であることを示して いよう.

\section{5. 結 論}

従来, 補強材により補強した土の補強メカニズムや補

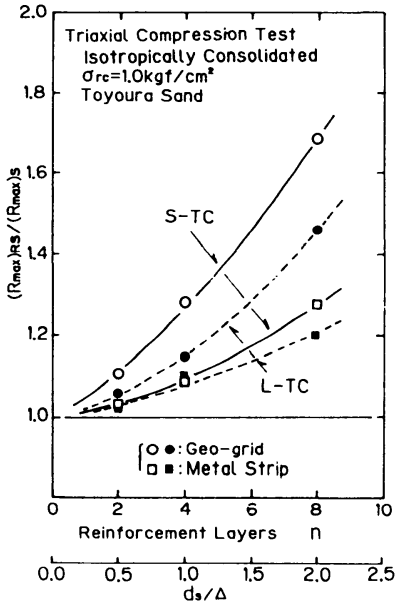

図一16 $d_{s} / \Delta$ と補強効果の関係

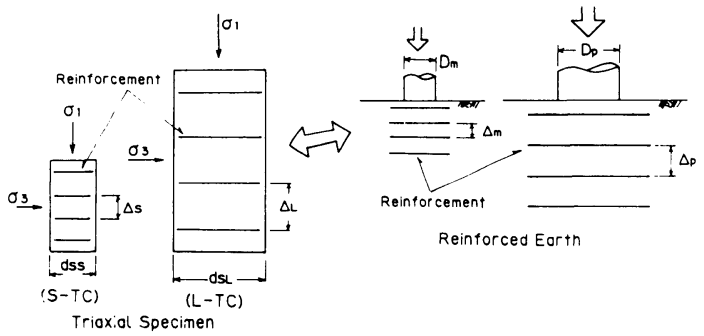

図-17 小型試験と大型試験 
強効果は供試体寸法の小さい室内要素試験により調べら れてきた。 また使用される補強材も，供試体寸法が小さ いという制約上，モデル化した補強材であった．本報告 では, 供試体寸法の大きい超大型三軸圧縮試験により, 実物補強材を現実にあり得る間隔で砂地盤中に配置した ときの効果について実験的に調べた。 その結果以下のこ とが明らかになった。

（1） ジオグリッドによる補強効果が最も大きいが (補強材間隔が小さい場合は特にそうである), この材 料を使用するときに注意すべきことは材料の破断に対す る検討を十分に行う必要があることである．ストリップ 材による補強効果は他の材料による場合よりも小さい変 形から現われる.

（2）補強材間隔が小さくなるほど補強効果は急激に 増加し, また補強材の種類による効果の差も大きくなる. しかし，現実にあり得る補強材間隔 $(70 \sim 100 \mathrm{~cm})$ で は材料による補強効果の差は小さいかあるいはほとんど ない。

（3）現実にあり得る間隔で砂の供試体に実物補強材 を配置すると最大応力比は 1 2 割ほど増加する.これ は内部摩擦角（式 (4)) で表わすと 3 4 度である.

（4）補強材の効果と拘束圧の関係はジオグリッドと ストリップで異なるが，これは両者の補強メカニズムの 相違によるものと思われる. つまりストリップでは主に 摩擦による補強であるのに対して, ジオグリッドでは砂 との摩擦だけでなく, インターロッキングも補強効果に 重要な役割をしているものと考えられる.この補強入力 ニズムの差は Mohr の応力円から求められる破壊包絡線 の差になって現われる.

（5）通常，補強材の効果はモデル補強材を用いた寸 法の小さい小型室内試験により調べることになるが,こ のような試験でも不織布のように材料自体の変形が大き い場合を除いて補強メカニズムのよく似たモデル補強材 を用いれば実物補強材の効果を定量的には難しいが定性 的な評価は可能である.

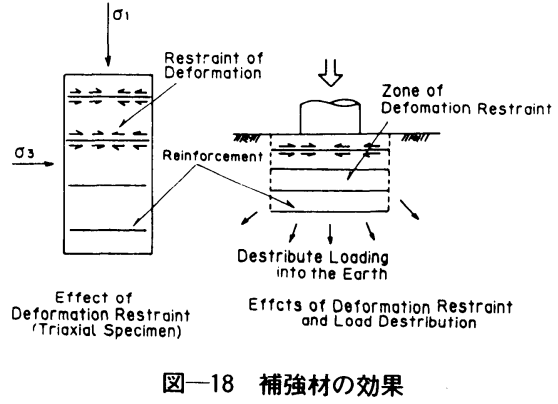

\section{6. あとがき}

以上述べてきたことは境界条件が明確な要素試験で調 ベることができる補強材による土の変形拘束の効果（土 亡補強材間に発生する摩擦による変形拘束）のみである (図一18 (a)). 実際の補強地盤における補強材の効果は, この変形拘束効果のほかに, 補強材により変形拘束され た部分が一体化し, 受けた荷重を周辺地盤に広く分散さ せる効果もある (図一18(b)). この応力分散効果はそ れぞれの構造物の境界条件に応じて決まるもので, 補強 地盤をより合理的に建設するには設計法にこの効果をど のように取り入れてゆくかが課題であろう.

\section{参 考 文 献}

1）龍岡文夫・金藤浩司・三木五三郎・生原 修 · 浜田英 治・佐藤剛司：引張補強材による砂の補強についての基 碳的研究, 土と基磫, Vol. 31, No.9, pp.11 19, 1983.

2）土質工学会編：補強土工法, 第 2 編メカニズムと設計の 基本, 1986.

3）鎌田正孝 - 石井武美 - 酒見徳行 - 小山田吉孝 - 栗原明美 : 砂による大型三軸圧縮試験機の検定, フジタ工業技術 研究所報, No. 12, pp. 85 92, 1975.

4) Ingold, T. S. : Reinforced Earth, Thomas Telford Ltd, pp. 95, London, 1982.

（1987.7.24 • 受付） 